\title{
GLOBALIZATION AND NATIONAL IDENTITY: THE ASPECTS OF POLITICAL ETHICS
}

\author{
Valdas Pruskus \\ Department of Philosophy and Political Theory, \\ Vilnius Gediminas Technical University, \\ Sauletekio al. 11, LT-10223 Vilnius, Lithuania \\ E-mail: politologija@vv.vgtu.It
}

\begin{abstract}
The article shows that globalization makes the largest influence on three significant guarantees of national identity (and freedom) preservation: language, economic and political independence. The possibilities to preserve and to consolidate freedom are discussed as well. The first theme analyzed is the worship and promotion of language, cultural and national values which mean not only safety but also openness and accessibility for other cultures (interchange). The second is the renunciation of servant position in relation with the European Union, the self-spread and defence of economic interests. The third is more active defend of political interests in the European Union in search for the partners whose interests seceded to coincide with ours. The fourth is the implementation of the political self-government principle, which should be grounded on the striving to preserve the national identity and culture which supply civil society. This way the gap between authorities and inhabitants decreases, it diminishes the distrust of citizens in authorities and it increases responsibility and accountability of authorities to the people who elected them. It is hoped that everything above mentioned would form more favourable environment for national self-awareness and freedom to spread and grow strong as well.
\end{abstract}

Keywords: freedom, globalization, national identity, national values, political ethics.

DOI: $10.3846 / 2029-0187.2008 .1 .199-209$

\section{Introduction}

Today nobody doubts that Lithuania comes back to the family of European nations. Lithuania unhesitatingly turned to the West, entrenching market's economy and value of democratic life. Universally uphold objectives of economic prosperity and unhesitating actions of government hastened Lithuania to become a fully-fledged member of the European Union (EU) and also hastened hopes of the citizens to reach higher standards of life. But Lithuanian involvement in the commonwealth of the EU and assuming obligation of membership (in the areas of economics, culture and politics) challenge its freedom, endowing to it new dimension.

Freedom became related to clearly designated purposes and responsibility. Lithuania, while becoming a part of commonwealth, where freedom of every state is closely related to another state's freedom, necessarily assumed other obligation which noticeably modified its understanding of freedom. Interdependence became a crucial element of freedom in various areas of social and political life. This process is more strengthened 
by all-inclusive globalization which proposes new model of all-inclusive freedom, which is predicated on free interchange of obligation and responsibility. Such new understanding of freedom challenges a nation, cultures and societies, budges its existential foundations.

The purpose of the article is to explain challenges of time (which is marked by a sing of universal globalization) to our freedom and possibilities of response.

\section{The challenges of globalization}

Globalization is a process which stimulates to promulgate scientific and technical achievements all over the world. According to this viewpoint it may be called a particular form of orthodoxy which includes all areas of life but the broadest influence is on two, the most important areas of human activity - economics and culture. True, the influence of globalization on mentioned areas is not equal.

Economics seems less vulnerable than culture. The attitude towards economics as a particular system of thinking is based on the model of individual's economic behaviour which is determined by the relation among the market participants. The paradigm of economic thinking is grounded on the motive of individual's reasoned activity. This motive marks all the effort of separate individuals, social groups and society in general. So it is versatile, universal (Bauman 2002: 45-48).

The cultural arena has not got a universal purpose. The culture (and its values) is differently realized and analyzed by representatives of various specialties (sociologists, philosophers). There is no unanimous viewpoint to what are the main motives and sources of cultural action, what stimulates to create cultural values (products). On the other hand, we have to notice that the culture precisely is the factor with the help of which weaker countries try to represent themselves to the world. Stronger countries usually represent their economic achievements, so at rules, which are proposed by globalization and which would become an assumption not only for development of universal market, but also for standards of appropriate cultural behaviour that would be suitable for representatives of all cultures, it is being looked at with eminently big distrust (Hofstede 2001).

It means, on the one hand, clear danger to lose cultural identity, increasingly entrenching new cultural preferences which are marked by the sing of universality. New cultural values and offered cultural products challenge steady societal cultural stability. Thus, it begins to infringe on cultural safety which is often marked with a clear mark of reticence and corporate solidarity.

On the other hand, it means the necessity to try to realize and accept new possibilities of interaction, collaboration and liaison with representatives of other cultures, to educate the spirit of hospitality. And it is neither easy, nor simple. But it is necessary (as to try to realize clearer) to recognize and define the singularity of valuable orientation and possibilities of the interplay, which may have influence on development of society and individual. And that is the most important. Despite stress and difficulties, which are impartial, the possibilities to take over cultural values are more or less equal to the nations. Another cup of tea is their wish and displayed endeavour. It is more difficult with possibilities in the economic area because here the inequality of possibilities is especially evident and it increasingly enlarges. 
Definitely, globalization is a serious challenge also for economics of national states. Information revolution enables to quickly transmit technologies of production manufacturing from one country to another, determines variation of economic structures, migration of workforce and capital and also stimulates processes of economic globalization (Hook 1997: 26-28), it is evident that a part of national states as effectual economic and politic power are decreasing. Despite the fact that the world makes a profit on that and this benefit salvages. Its limit: society becomes more productive and effectual because there appear possibilities to use technologies of the newest manufacture and management in order to seek the universal welfare and safety. This safety is a result of the increase of global economy safety (Barro 1995). But it is evident that societies, while becoming safer, do not become more truthful.

True, the confidence of more private than collective initiative is growing and it is being more approvingly looked at the reduction of function of state regulation, more and more one's voice for privatization is given. However, there are own winners and losers in this process. It means that inequality of possibilities in economic area, which is determined by specific circumstances of historic development and by forms of life, remains. What is more, the reality of economic development, that is the split between scanty and wealthy counties, expands. This fact stimulates to discuss whether globalization really gives equal possibilities of economic development for all nations and necessarily grows national product over the globalization.

Thus, there is no unanimous viewpoint whether during globalization processes globalization is good or bad, whether it enlarges or reduces the split between advanced and undeveloped countries, whether poverty decreases or not.

Globalisers state that during globalization's process the inequality between countries reduces. As an argument for this, such indicators as the growth of domestic product (GDP) for one resident and growth of yearly per capita income (Masusyma 1997) are invoking.

Antiglobalisers object: such behaviour is not possible because countries are of different size, for example, China and Saudi Arabia. There are more residents in China, therefore, the GDP is bigger, i.e. there are more products created in China than in Saudi Arabia, but there are more residents, therefore, for one resident there is less product than in Saudi Arabia. It means that the touchstone of GDP for one resident here does not apply.

Secondly, per capita income cannot be the touchstone of growth too because there is a difference of currency unit's purchasing power. For example, what is possible to buy for Yuan or a Pound? It is evident that its purchasing power will be different. Therefore, in order to compare per capita income, complicated conversion of currency unit's purchasing power is necessary to compare with other currencies. Moreover, it should be remembered that some countries have been counting the growth of the GDP for a long time and other began to do that recently. Therefore, it is difficult to determine the tendencies and consistent patterns of the GDP.

There is no unanimous viewpoint to the growth of poverty. Globalisers state that poverty is abating because of economic globalization (20 years ago paupers made 30 percent of all resident, now - about 20 percent).

Antiglobalisers appeal to statistics and argue that poverty is not abating in the world: rich advanced countries keep on becoming wealthy, and poor ones keep on becoming poorer. 
What is more, the split between them enlarges (in 2006, according to the information of the United Nations (UN), 20 percent of the income of poor countries "residents" reached 10 percent average of income of developed countries.).

The inequality between residents enlarges too. For example, Slovenia and Saudi Arabia: in both countries there is equal income for one resident. But the inequality is more evident in Saudi Arabia, where such distribution is clearer in Slovenia.

It should be noticed that selected criteria have crucial significance during valuation of poverty. According to experience, different parameters of poverty in the countries are applied. To put it in other words, to the "bag of poverty" there are out different things. (For instance, the limit of poverty in the United States of America (USA) and Lithuania yearly per capita income).

In order to be truthful, it should be acknowledged that in case of using absolute numbers the poverty is reducing in the countries.

Despite this, there are unarguable positive factors of globalization, which stimulate the development of economic powers and enforce to explore every avenue, and which have influence on the living style (Rao 1998). Bigger possibilities to use not only material goods and services, which are marked by universal signs (for example, jeans, coca cola, etc.), but also cultural values (films which are accepted in the world, literary writings etc.) appear. In turn it has influence, on the one hand, on the functioning of economics and economic behaviour of individuals, on the other hand, on the alternation of the understanding of cultural behaviour and cultural role in the societal life.

So, it is possible to say that globalization:

Stimulates the development of economic and cultural values (subverts walls) and this way gives new possibilities for the individual and society.

Requires absorbing, entrenching it and transforming into the "working values". To put it in other words, the necessity of material and nonmaterial human needs gratifying predicates on it.

It is believable that due to its take-over will be created new quality of social, cultural and political life. And this will have influence not only on further development of economics but also on new paradigms of societal development, which incorporate economic, social, political, ecological and cultural factors intro unanimous totality (Paecock, Idle 1998).

These mentioned factors will become crucial in trying to determine requirements of social and cultural projects' admissibility to society which would become the criteria of the democratization of society, its stability and maintaining. Such might be:

The maintaining of the balance between the objectives of economic welfare and societal spiritual cultural needs (i.e. to what degree it is matched to the proportion of material and not material welfare, while realizing the projects);

The observance in veracity relations between separate social groups and in domestic relations (whether artificial barriers to assert in certain areas of activity are not made, whether everyone, despite social status, gender, nationality etc. has equal rights and possibilities to employ desirable activity);

The existence of maintaining variety and support economics in cultural and other areas of human activities; 
The existence of mechanism which are able to protect society from irresponsible and indiscreet decision of government and economic structures (i.e. to what degree equal development of various cultural forms is sustained, not excepting some as special, what are the circumstances to employ the creators, how it secured the independence of these cultural systems - economic, social, ideological).

The latter is very important in order to save cultural "ecosystems" because it is known that realistic economy pay less attention on it than on saving natural ecosystems. It is because the natural resources are the main source of economic manufacture.

On the other hand, it is evident that disavowal of cultural and human capital, not enough valuation of its importance may cause real danger for the destiny of natural capital: while tolerating thoughtless emaciation of natural resources, there is a risk to lose it as important resources of manufacture, and that will have an impact on economic development (Griffin 1996).

Thus globalization not only brings the necessity of cultural and economic interplay, while seeking societal welfare, up-to-date, but also challenges nations, cultures and societies, (Held 1995) and for its existential foundations, giving dimension of universality, which means new dangers and tests.

One of them is intensifying individualism. The point is that globalization, which is displayed not only by the free movement of workforce and capital, but also by intensifying interchange of cultural products, formats a person of a new type - immigrant, globalist, which enshrines individualism and demonstrates unwillingness to relate oneself with societal standards and values, to belong to it. That principle to "opt out" became particular inclusion to community of individualities. It is known that individuality destroys the national feeling "we", which is formed on the basis of commonality of historically formed culture, language, theory, economics and life. On such circumstances modern state loses its foundation - national identity. And cultural identity is substantial part of national identity, which mainly feed juice of individual and national freedom, lending strength. No force of the North Atlantic Treaty Organization (NATO) could protect Lithuania, if it was not protected by Lithuanians, who lost their identity, traditions and became apathetic to its destiny. It is possible to protect territory, but it is impossible to protect nation, which is apathetic to its roots and state.

The next test is the usage of culture. Economic globalization implicates in its guided markets and culture, which more and more becomes a product of grassroots usages. Apace is internationalized industry of entertainment (movies, music, fashion and so on). Thus globalization challenges national cultures, which down the ages developed its internal code, according to which it accepts and traps influences of global process. Now this code incurs strong enforcement, which is more and more difficult to withstand. Undoubtedly, informational technologies also have influence on that. Internet imparts and helps to implant cultural values, viewpoints to social relation, family, religion, human existence and so on. These values, being new and absorbing, can stimulate (and stimulates) query about traditional cultures and overrun it. Cultural domination becomes very serious problem then, when propagates false values, which are antagonistic to the real good of single individuals or its groups. Today's status is special because the modern informational facilities 
transmit valuable culture of West to societies and people, which often are not ready to evaluate and accept it. Thus the freedom to accept becomes captivity while accepting.

Blindfold tapping and copying of cultural and administrational governmental products, which are proposed by the West, we often voluntarily abdicate our freedom to life, do not try to protect this right. We have our traditions, customs, subculture, which must be respected and protected. The attempts shown in nurturance of national traditions, customs, styles of life, best bear witness to the ripeness of its freedom.

The third test is a value pluralism and relativism which smears clear limits between good and bad. While accepting various value attitudes, society loses orientation. Moral authorities, the voice of which would be heard, are abating; they are more upstaged by heralds of aggressive media. While going downhill the authority of high-ranking civil servants of state instructions, parties over imputations of various faults, the power and influence of irresponsible media enlarges: it becomes almost the most powerful maker of national and civil value attitudes (this is shown by sociological surveys). The maker of such attributes, which are often opposite to national traditions and even to its objective of freedom, but not to media.

Thus "free" press suggesting "its" values and models of events and phenomenon, harbours designs on the freedom of citizenry to achieve objective information, not its interpretations. Thus it, on the one hand, becomes dangerous to itself, because it does not operate proper functions - firstly, to give objective, unbiased information and risks to degrade. On the other hand, it becomes dangerous to citizenry too, because, despite the variety of proclaimed opinions, it does not concede for citizens the freedom to choose and adjudicate by themselves, because objective, unbiased information more and more becomes an item in short supply, which is searched outwards Lithuania. Thirdly, it is dangerous to the state, because value attitudes and tendentious information, wild guesses and hearsays, which more and more become a devouring item in its assortment of services and one of the main sources of the living of its market, not only belittler state and its institutions in the eyes of citizenry, but also noticeably aggravate projects, which are meant to seek for common welfare. In this way it is also infringed on its freedom. What is more, its attempts to do enforcement for juridical institutions are evident, in turn it is stimulating juridical nihilism.

The fourth test is the freedom of religion's confession, which allows for aggressive sects to proliferate, which is dangerous to individual and society.

The influence of Catholic Church on Christian dimension of Lithuanian social cultural identity is unquestionable. It determined integrity during the years of occupation, also during nurturance of self-contained state's hope in the hearts of people. However, it is impossible not to notice the fact that the influence of it, as announcer and fosterer of universal values, is abating, because the approval to these institutions is abating in society: postmodern value pluralism entrenches, more often values, which were put as undoubted by society, are verified.

The church gradually loses its influence and more often it is understood as the organization, which is advantageous for society and state as much as it undertakes social works, which are not put as "prestige" (explicated activity of "Caritas" organizations in bishoprics) 
and defends only insular interests of congregation. The separation of the church from the state and acceptance of the freedom of persuasion does not yet mean state's right to walk away from contemplation of questions, which are actual for the church as institution, and from making certain conditions to its fully-fledged working, also from disinterest in pervasive religious movement and its influence on the society. (The bigger part of society constitutes congregation - Catholics, as citizens paying taxes for its state and having the right to its concern). It only shows the absence of clear and consistent politics in regard with religion. Abstract declaration of religious freedom makes beneficial hotbed for aggressive sects to develop their activity, which has negative influence on social and psychological security of citizenry. The acknowledgment of religious freedom to operate for penetrating and aggressive unconventional religious movements became captivity for citizenry. Religious freedom becomes irresponsible freedom to propagate standpoints, which are not salutary and acceptable, menaces not only for citizenry, but also to the state.

The fifth test on the law is the ascendancy of the law and parity of everybody against the law and is a clear thing in societies of the West, therefore citizenry feel safe because they know that they are defended by legislative enactment. In turn they are ready to show obedience to it, because they realize observance of law as the only civilized way to deal with their matters and to seek for their interests (imbibed civil responsibility). Lithuania, after the renewal of Independence, also hustled to create juridical basis of state's operating. In the main country Law - the Constitution - there were entrenched attitudes which satisfied expectations of society. But soon it appeared that it is not enough to have rights, the appropriate facilities and powers are necessary for its realization. And there was no mechanism for such realization. Soon the watershed between Law (its creators) and society (its executers) showed up. Astute people and interested groups undertook to search ways how to circumvent the law, and this for then, when corruption was widely prevalent, easily done it. In the juridical valuation of transgressions of public officials and high rank officeholders, the practice of double standards is used, and it more stimulated juridical nihilism and disrespect of the law. Thus, mentioned realities of juridical life, procreated by good juridical intentions, become dangerous for the freedom of state operation, aggravate execution of the EU membership responsibilities.

The biggest influence globalization has on three most important guarantors of the preservation of national identity - on language, economic independence and politic amateurish.

Firstly, the influence is on the essential element of national culture - on language. National language gradually loses its importance, because less gratifies the individual who is more and more dependent on consumer society subculture and new traditions, dictated by the market. The point is that the English language as the single language of communication and collaboration increasingly entrenches and it supersedes to edges of speech space mother-tongue. Unfortunately, this situation is being tolerated. Not showing respect to the mother-tongue, irregular its usage of office-holders and high rank official publicity, push away from the activities in scientific academic areas and replacing it by England, is today's reality. Thus Lithuanian, which in the beginning of $20^{\text {th }}$ century was one of the most important features to save the freedom and national 
identity and over its right it was gamely struggled, noticeably relinquishes its positions. Although officially the Lithuanian language is one of the EU usable working languages, but according to the facts, it is not used in all events, as it is provided in the rules of the EU. And the fault is of our governmental institutions, which insufficiently care about that. So the rights of Lithuanian language are not only not defended, but the image of the state is also belittled.

Another not less important globalization's upshot is going downhill of economic self-sufficiency. The reality is that Lithuanian economics, while more and more integrating in global economics, necessarily loses its self-sufficiency, becomes more dependent on the economics of the world. On the other hand, in the conditions of free movement of capital and work, foreign capital is increasingly entrenching in Lithuania. Local capital is unable to compete, and relinquishes its position in most sectors of economics. Lithuanians become an actual problem. Communal Lithuanian economic capability is weaker than in other advanced countries, thus there is a real danger that in Lithuania economic fashion may be dictated (and is dictated) by others, the representatives of foreign countries, who have their own purposes and requirements. The capital does not have sentiments. Money does not have smell, but does have power. The same is with politicians. Thus, there is presumption to think that economic self-sufficiency is going downhill also belittles political self-sufficiency. Therefore, the invitation and attempts of national revival's ideologists of the beginning of XX century sounds especially actually, that is to stimulate the formation of stratum of homey businessmen, which would become active economic and cultural monitory, which would uphold the longevity of national identity, using its source and position. On the other hand, the capability of the economic state is one important guarantor of its freedom.

The third challenge is the going downhill of political self-sufficiency. Being the member of the EU, Lithuania delegates a part of sovereignty in the EU and this way it refuses a part of self-sufficiency. The law is prevailing and we have to obey it. And this belittles the confidence of our state, of its authority. Declining confidence of the own state, of official competence of its institutions and of ability to determine important economic and social questions enlarges the emigration of the youth, and this stimulates not only worsening of national self-consciousness, but also reduces places of potential, state's defenders.

On the other hand, it is evident that Lithuania has its ruling elite, but it hardly has power elite, which is characterized by the self-consciousness of the group, communal interests and common will, expressed by three characteristics: self-consciousness, solidarity and conspiracy. Seeing Lithuanian "silent obedience", the EU (especially the biggest Member States) is not very minded to respect its vital interests. It is looked at that, as at country, which during centuries was governed by foreigners, which does not have its strict position on the most important questions and unable to defend it. Its political elite are infantile, constantly explaining interrelations and not exploring it, without having clear viewpoint of the future of Lithuania. Being unsure over its future, it is looking not only at the West, but also at the East. Thus, knowing "uncomplaining" temper of Lithuania, the EU looks at it reservedly and does not respect its interests too much. 
Thus, as we see, globalization, which thrusts upon the world its universal rules of economic processes, noticeably aggravated possibilities to protect the freedom and national identity. What response is possible to the mentioned challenges?

\section{The possibilities of response to globalization's challenges}

The first: The respect and nurturance of our language, cultural and national values. Europe is very clearly decided to be cultural tangle, because culture of every nation is European value. The EU is in the mood to safeguard, uphold and develop national identity. Everyone, evaluating oneself, must respect values of others. Values are not everlasting too; they cannot remain unaffected by the spirit of time. The respect for nation values is important, but it is evident that we like to lose our nation more, if we did not propagate our national values. Only upholding it, we will be respected and interesting to ourselves and to others. On the other hand, we cannot forget that revelation and nurturance of cultural heritage is significant only in the context of the EU cultural heritage. It means the necessity not only to be interested in cultures of new neighbors, but also to absorb it and this way seek for new quality of economic, political and cultural life.

The second: The reduction of antithesis between state and citizenry. Lithuania, becoming a member of the EU, must try to overcome antagonism to the law and acts, which is still alive in society. On the one hand it means bigger attempts of state ant its institutions in seeking for openness and accessibility for citizenry, attention on their troubles and real help, what undoubtedly would reduce watershed between state and citizenry. On the other hand, it means the adoption of law, which echo requirements and expectations. Of citizenry, universal necessity and transparency of its observance; this would stimulate the pride of our country and the wish to concern our and our children's future with it.

The third: More active defense of economic interests. Joining the EU we have to protect our interest and respect interests of others. It is unavoidable. In order to do it effectively, it is necessary to acknowledge other states of commonwealth, the interests of which coincide with ours, and join with it. In this way it is possible to protect our economic interests better. What is also important is single-minded, orientated to the future support strategy of our business and businessmen as social stratum. It should become constituent part of state's politics - not by words, but by concrete actions. It is likely that it would not only make conditions for Lithuanian capital's staying in the country, but also would stimulate its return to Lithuania. In such way there would be made advantageous conditions for middle stratum to grow, which may finance national projects and initiatives, it also would reinforce the foundations of the freedom.

The fourth: More active protection of our political interests. Being the member of the EU, Lithuania should participate in making decisions more actively, to suggest initiatives and this way to fight out the authority in the EU. Political activity of the state, upheld by citizenry, would make more advantageous conditions for national identity to fuzz and for realized and responsible ripeness of freedom.

It is evident that the ripeness of national freedom is dependent on societal active minority and powers and attempts of inactive majority, and on its balance. But today's 
realities are such that we cannot rely only on keeping the balance of spontaneous powers of community religion. National freedom, on the guarantee of is surviving, the succession of cultural values, becomes more and more political state its management body. Undoubtedly, its responsibility for preservation of national freedom, identity, auto-suggestion also grows, as well as for preservation and for giving a sense to historic memory. The state, which does not preserve historic memory, is ticking losing the future.

As we see, the challenges to our freedom is reality, which must be reconciled. Every time it proliferates. The challenges are as new signs on the road: maybe not all are acceptable for us, but in order to reach the purpose, we should notice it, because it is us who is responsible for safe driving.

And freedom is like a pie, which is put on the table of life's treat: you may slice as much as you want, but you may eat as much as you can.

\section{Conclusions}

After the restoration of the Independence Lithuania unhesitatingly turned to the West to strengthen market economy, values of democratic life and apotheosis of freedom. The partnership in commonwealth of the EU and accepting responsibilities of membership (in the areas of politics, economics, culture, etc.) challenges its freedom too. It is evident that our freedom is determined by rapid changes, which are marked by signs of universal globalization. Intensive individualism, the usage of culture, value pluralism and relativism are the challenges, which stimulate to look at our attempts not only to protect and entrench our freedom, but also to protect our national identity, self-awareness and autosuggestion, which best bear witness to the existence of freedom in the conditions of universal globalization.

The biggest influence globalization has three the most important guarantees of protecting national identity (and freedom) - on language, economic independence and political independence.

It is possible to single out few means of consolidation of national identity. Firstly, it is respect and propagating of language, a cultural and national value, which means not only security, but also openness and acceptability for other cultures (interchange). Secondly, the refusal of servile position in the relation with the EU, the defense of effective and single-minded economic interests, which echo vital national self-propagation of its parts, especially businessmen. Thirdly, more active defense of political interests in the EU, seeking for partners, whose interests coincide with ours. In this way it is possible to earn bigger benevolence and support. Fourthly, the realization of the principles of political self-government, which would be predicated not on the formal returning of various level government, but would be relied on objective of preservation of national identity, its culture, which is feeding civil society. In this way the split between government and citizenry reduces, in the same way the citizenry distrust of the government would reduce as well, it would enlarge its responsibility and clearance for the citizenry. It is likely that all this would format more advantageous hotbed to propagate and strengthen national self-awareness and freedom. 


\title{
References
}

Barro, R. J. 1995. Economics Growth. New York: MacGraw-Hill.

Bauman, Z. 2002. Globalizacija: pasekmès žmogui. Vilnius: Strofa.

Griffin, K. 1996. Studies in Globalization and Economic Transitions. London: Macmillan.

Held, D. 1995. Democracy and the Global Order: From the Modern State to Cosmopolitan Governance. Cambridge: Polity Press.

Hook, S. 1997. Human Values and Economic Policy. New York: MacGraw-Hill.

Hofstede, G. 2001. Culture's Consequences. London: Sage.

Masusyma, S.; Vandenbrink, D.; Siow Yue, Ch. (eds.). 1997. Industrial Policies in East Asia. Tokyo: Nomura Reasearch Institute.

Paecock, A.; Idle, R. (eds). 1998. Cultural Economics and Cultural Polities. Dordrecht: Kluwer Academic Publishers.

Rao, C. (ed.). 1998. Globalization, Privatization and Free Market Economy. Westport: Quarum Books.

\section{GLOBALIZACIJA IR TAUTINIS TAPATUMAS: POLITINĖS ETIKOS ASPEKTAI}

\author{
Valdas Pruskus
}

\section{Santrauka}

Straipsnyje parodoma, kad tautinio tapatumo kaip vertybès ir laisvès tapsmą vis labiau lemia spartūs pokyčiai, paženklinti visuotine globalizacija. Atskleidžiama, kad didžiausią poveiki globalizacija daro trims svarbiausioms tautinio tapatumo (ir laisvès) išsaugojimo garantams - kalbai, ekonominiam savarankiškumui ir politiniam savarankiškumui. Aptariamos tautinio tapatumo ir laisvès saugos bei jos ittvirtinimo galimybès. Pirma, tai - kalbos, kultūrinių ir tautinių vertybių gerbimas ir propagavimas, kuris reiškia ne tik apsaugą, bet ir atvirumą bei prieinamumą kitoms kultūroms (mainus). Antra, atsisakymas servilistinès santykių su ES pozicijos, efektyvus ir kryptingas ekonominių interesų, susijusių su gyvybine tautos, atskirų jos grupių savisklaida, gynimas. Trečia, aktyvus politinių interesų gynimas ES ir partnerių, kurių interesai sutaptų su mūsiškiais, paieška leistų pelnyti didesni palankumą ir paramą. Ketvirta, politinès savivaldos principo igyvendinimas, kuris būtų grindžiamas ne tiek formaliu visų lygių valdžios renkamumu, bet remtųsi tautos tapatumo, jos kultūros, kuri būtent ir maitina pilietinę visuomenę, išsaugojimo siekiu. Taip pat mažinamas (atkuriamas) valdžios ir gyventojų atotrūkis silpnintų ir nepasitikejjimą valdžia, didintų jos atsakomybę rinkèjams.

Reikšminiai žodžiai: globalizacija, tautinis tapatumas, laisvè, tautinès vertybès, politinè etika. 